Jackson, Jane. Online Intercultural Education and Study Abroad: Theory into Practice. New York, NY: Routledge, 2018. pp. 243. Website: https://www.routledge. com

Knight, Jane, and Emnet Tadesse Woldegiorgis, eds. Regionalization of African Higher Education. Rotterdam: Sense Publishers, 2017. pp. 249. Website: https:// www.sensepublishers.com/catalogs/bookseries/african-highereducation/regionalization-ofafrican-higher-education/

Maringe, Felix, Emmanuel Ojo, eds. Sustainable Transformation in African Higher Education: Research, Governance, Gender, Funding, Teaching and Learning in the African University. Rotterdam: Sense Publishers, 2018. pp. 249. Website: https://www. sensepublishers.com/catalogs/ bookseries/other-books/sus- tainable-transformation-in-african-higher-education/

Mattingly, Paul H. American Academic Cultures: A History of Higher Education. Chicago, III: University of Chicago Press, 2018. pp. 423. Website: https:// www.press.uchicago.edu/ ucp/books/book/chicago/A/ bo27128771.html

Muoghalu, Caroline Okumdi. Leadership and Crises in Nigerian Universities Can Women Make a Difference? Dakar, SN: CODESRIA, 2018. pp. 136. Website: http://www.codesria.org/carnegie/leadership-and-crises-in-nigerian-universities-can-womenmake-a-difference/

Oleksiyenko, Anatoly V., Qiang Zha, Igor Chirikov, and Jun Li, eds. International Status Anxiety and Higher Education: The Soviet Legacy in China and Russia.
Hong Kong, China: Comparative Education Research Centre, University of Hong Kong, 2018. pp. 402. Website: https://cerc. edu.hku.hk/books/internationalstatus-anxiety-and-higher-education-the-soviet-legacy-in-chinarussia/

Rapoport, Anatoli, ed. Competing Frameworks: Global and $\mathrm{Na-}$ tional in Citizenship Education. Charlotte, NC: Information Age Publishing Inc, 2019. pp. 252. Website: https://www.infoagepub.com/products/CompetingFrameworks

Varghese, N. V., Anupam Pochauri, and Satyanton Mandal, eds. Indian Higher Education: Teaching, Learning, and Quality in Higher Education. New Delhi: Sage, 2018. pp. 377. Website: https://in.sagepub.com/ en-in/sas/product/Indian\%20 Higher\%2OEducation\%3A\%2O
Teach i n g \% 2 C \% 20 Learning\%2C\%2oand\%20Quality\%20in\%2oHigher

Wright, Susan, and Chris Shore, eds. Death of the Public University. Uncertain Futures for Higher Education in the Knowledge Economy. New York, NY: Berghahn Books, 2017. pp. 338. Website: https://www.berghahnbooks. com/title/WrightDeath

Zapp, Mike, Marcelo Marques, and Justin J. W. Powell, eds. European Educational Research (Re) Constructed: Institutional Change in Germany, the United Kingdom, Norway, and the European Union. Oxford, UK: Symposium Books, 2018. pp. 253. Website: http:// www.symposium-books.co.uk/ bookdetails/102/

\section{NEW PUBLICATIONS FROM CIHE}

Liu, Xinyan. Language of Instruction in Higher Education. CIHE Perspectives No. IO. This report showcases research undertaken by Xinyan (Sissi) Liu, a student in CIHE's Master of Arts program in International Higher Education. It is a joint product of CIHE and the International Association of Universities (IAU), and addresses how language is playing out in higher education institutions and systems around the world, in an age in which the English language so effectively dominates the global landscape of politics, economics, and highly cited research. https://www.bc.edu/ content/dam/bci/schools/lsoe/sites/cihe/CIHE\%2oPerspectives\%20I0_I8_DEC20I8_FINAL.pdf

Rumbley, Laura E., and Hans de Wit, eds. Innovative and Inclusive Internationalization: Proceedings of the WESCIHE Summer Institute, June 20-22, 2018, Boston College. CIHE Perspectives No. II. This issue is the result of a cooperation between World Education Services (WES), headquartered in New York, and CIHE, and is based on the findings of the 2018 WES-CIHE Summer Institute on Innovative and Inclusive Internationalization in Higher Edu- cation. The collective result of the research by MA and PhD students provides meaningful insights into internationalization of higher education as perceived and studied by the next generation.

https://www.bc.edu/content/dam/bci/schools/lsoe/sites/ cihe/Perspectives\%20No\%20II\%20\%20Jan\%20IIth\%2O 20I9\%20FINAL\%20TO\%20PRINT.pdf

Wu, Yan, Qi Wang, and Nian Cai Liu, eds. World-Class Universities: Towards a Global Common Good and Seeking National and Institutional Contributions. Global Perspectives on Higher Education, Volume: 42. Based on the findings of the Seventh International Conference on World-Class Universities, World-Class Universities provides updated insights and debates on how world-class universities will contribute to the global common good and, in doing so, will balance their global, national, and local roles. https://brill.com/abstract/title/39594. ISBN: 978-90-04-38963-2 DOI: https:// doi.org/ıo.1163/9789004389632 